\title{
RESEARCH
}

\section{Impact of Transitioning a Senior Seminar Capstone Course from Weekly Classes to an Intensive Hybrid Course}

\author{
Jamie L. Miller, PharmD, ${ }^{\mathrm{a}}$ Misty M. Miller, PharmD, ${ }^{\mathrm{a}}$ Stephen B. Neely, MPH, ${ }^{\mathrm{a}}$ Melissa S. Medina, EdD ${ }^{\mathrm{a}, \mathrm{b}}$ \\ ${ }^{\text {a }}$ University of Oklahoma Health Sciences Center College of Pharmacy \\ ${ }^{\mathrm{b}}$ Associate Editor, American Journal of Pharmaceutical Education, Arlington, Virginia
}

Corresponding Author: Jamie L. Miller, University of Oklahoma Health Sciences Center, College of Pharmacy, 1110 N. Stonewall Ave., Oklahoma City, OK 73117. Tel: 405-271-6878. Email: Jamie-miller@ ouhsc.edu

Submitted October 6, 2021; accepted February 4, 2022; ePublished February 2022

\begin{abstract}
Objective. To compare outcomes (grades, resources, and perceptions) from a weekly in-person seminar capstone course (pre-course change group) to an intensive hybrid course design that included a two-day in-person conference (10 and 25minute student presentations) and asynchronous seminar skills sessions (post-course change group).

Methods. Students' scores on seminar presentation rubrics were compared pre- and post-course change. Resources such as number of faculty and hours of involvement, and student time away from Advanced Pharmacy Practice Experiences (APPEs) were compared between groups. Student and faculty satisfaction and perception were also assessed.

Comparisons between groups were made using independent t-tests or Chi-Square tests. Descriptive statistics were used to summarize student performance and survey responses.

Results. Three-hundred seventy students, 205 (pre-course change) and 165 (post-course change), were included. There was no significant difference in mean overall scores for the 25-minute presentation between groups; however, the postcourse change group had significantly lower scores on the objectives and slides subscores and significantly higher critical analysis subscores. The survey was completed by $82 \%$ of faculty and $43 \%$ of students from the class of 2018 . A majority of students $(80 \%)$ found all of the asynchronous sessions helpful and $70.6 \%$ preferred the intensive hybrid course format. Compared to the weekly format, all faculty reported student presentations were similar or better in quality and workload was similar or decreased with the intensive hybrid format.

Conclusion. The senior seminar capstone course change to an intensive hybrid design reduced faculty workload and decreased student time away from APPEs, while maintaining similar presentation grades and quality.

Keywords: pharmacy, seminar, education, curriculum, curricular assessment
\end{abstract}

\section{INTRODUCTION}

Capstone courses, such as senior seminar courses, are one way to assess students' higher-level application of critical thinking, problem solving, educating, communication, and professionalism skills. This type of course, designated to have students utilize their drug information skills to research a clinical controversy and formally present their recommendations to peers and faculty, has been previously described in the literature. ${ }^{1-9}$ However, capstone courses can significantly vary in expectations, training, delivery method, and time commitment, especially when they occur during students' Advanced Pharmacy Practice Experience (APPE) year. While the concept of a capstone course may not be new for programs, the literature has not reported the outcomes of delivering a seminar capstone course over different timeframes such as an intensive hybrid course design.

Use of intensive courses have increased but the evidence comparing these formats to traditional semester formats is lacking. ${ }^{10}$ The lack of evidence may be due to the term "intensive", which could mean time-reduced/accelerated or rigorous; the term and definition is crucial. ${ }^{10-12}$ For example, one study found that an intensive Pharmacotherapy Scholars Program for fourth year pharmacy students resulted in high residency placement rates and significant improvements to knowledge and clinical skills, however, this intensive course was a year-long program that focused on rigor. ${ }^{11}$ Intensive or accelerated teaching is defined as being offered in less time or fewer contact hours than normal and studies have shown that compared to traditional formats there is no difference in outcomes. ${ }^{12,13}$ Harwood and colleagues found no statistically significant differences on student performance (final assignments or course grades) and student satisfaction (course evaluation ratings) in an intensive (7-week) course compared to traditional semester long course (15-week) in three graduate health science programs. ${ }^{10}$ While this study was conducted with students in health science programs, it did not evaluate doctor of pharmacy students specifically. 
A senior seminar capstone is an appealing course to adapt into an intensive/reduced contact time format since it occurs during the APPE year when programs want to maximize the amount of time spent at an experiential site. Factors such as proximity of APPE rotation sites to campus, faculty availability, and classroom space are impacted during a traditional weekly class structure. While an intensive course structure may impact these areas to a lesser degree, it is important to ensure that the format does not negatively impact students' learning outcomes. The current study was designed to evaluate the feasibility and impact on student performance of transitioning a traditional weekly seminar capstone course into an intensive time frame of self-study plus two in-person sessions. This study is unique because in addition to assessing the impact of an intensive hybrid course design with two synchronous face-to-face sessions on learning outcomes, it also evaluated the use of a hybrid format that included asynchronous videos. The primary objective of the study was to compare seminar presentation grades pre- and post-course change. A second objective was to compare the resources needed pre- and post-course change including faculty and student time, number of faculty, and workload. The third objective was to capture perceptions of the students and faculty participating in the first year of the intensive hybrid course design.

\section{METHODS}

Since 2001, the University of Oklahoma College of Pharmacy has required a two-credit hour senior seminar capstone course for all Doctor of Pharmacy students during their APPE. Historically, the course met once weekly for two hours during designated months in the fall and spring semester (ie, 19 two-hour sessions). During these weekly meetings, students completed five sessions of seminar preparation workshops (ie, presentation skills; writing objectives and assessment questions; creating presentation slides and handouts; refreshing statistical principles; and referencing and citing literature) according to continuing education/continuing professional development guidelines. Students then formally applied these skills and analyzed primary literature to present a clinical controversy to a small peer group and a full-time college of pharmacy faculty member. Each student delivered a 10-minute presentation during one of five weekly sessions in the fall semester, and an expanded 25-minute presentation during one of six weekly sessions in the spring semester. Students also participated in two Professional Skills Workshops (eg, curriculum vitae/resume review, interview skills, dining etiquette) in the course where they received formative feedback about career skills, as well as one session of pharmacy law review.

Due to a programmatic change at the College that resulted in a distant campus closure and a reduction in faculty in spring 2017, a major change in the course structure was required. In the 2017-2018 academic year, the weekly class sessions were changed to asynchronous self-study during June and July of the fourth professional year, using eight videos, which were class recordings from the live delivery in the previous year and on-line quizzes. This was followed by two intensive days of face-to-face student presentation sessions, with a four-hour session in the fall (August) and eight-hour session in the spring (January). Students presented to their assigned group of 10-14 students and a full-time college of pharmacy faculty member. Despite these changes, the course retained the same credit hours, content, goals, and activities of the previous weekly course design. Students were required to complete all activities, attend all of the presentations in their assigned group, provide feedback to their peers, and achieve a grade of $70 \%$ on the spring 25 -minute presentation to pass the course. Overall, this structural change provided an opportunity to compare the outcomes of this change in course delivery.

A locally designed presentation rubric was developed and utilized for evaluating the 10-minute and 25-minute seminar presentations. The 10-minute presentation rubric was weighted more heavily on evaluating the formatting of the handout and slides, development of objectives, and timing of presentation; whereas the 25-minute presentation rubric included the areas listed above but with greater emphasis on analyzing, critiquing, and applying primary literature. The rubrics were modified since inception of the course in 2001, but have been consistent in content since 2010. All graders were trained on the rubrics and inter-rater reliability was established. A total of 100 points are available on the spring presentation rubric and specific subsections have a designated number of maximum points (Figure 1). For this study, the overall scores, subsection scores, and percentage of students with a spring presentation grade $<70 \%$ were compared between the pre- and post-course change groups. The specific subsections of objectives, handout, slides, assessment questions, and critical analysis were selected for comparison because they were heavily emphasized in the seminar preparation sessions.

This study included the academic years of 2015-2017 for the weekly seminar course format ("pre-course change") and 2017-2019 for the hybrid asynchronous and two-day conference format ("post-course change"). All students ( $\mathrm{n}=370$ ) enrolled in the course during these time periods were included. The 2019-2020 academic year was not included in the post-course change group because of the requirement to deliver the entire course virtually due to the COVID-19 pandemic. To determine faculty workload, the number of faculty and hours spent in the classroom grading presentations were calculated for the pre- and post-course change periods. In addition, in an effort to determine time away from APPE 
activities, the hours students spent in the classroom were also calculated for the pre- and post-course change periods. Travel time from APPE site to the college of pharmacy was not included in this calculation.

Two locally developed electronic surveys were distributed to the students and faculty involved in the 2017-2018 senior seminar course at the end of the spring semester (ie, the first post-course change year). The student survey (39 questions) assessed the students' perception of helpfulness of the seminar preparation videos and quizzes, satisfaction with course design, and preference for course format. The faculty survey (8 questions) assessed their perceptions of presentation quality, course workload, and course format satisfaction. Eighty students from the class of 2018 and 11 faculty graders for the spring presentations (excluding the two course coordinators) were invited to complete the respective survey and were emailed one reminder after two weeks.

Descriptive statistics including mean \pm standard deviation and frequency (percent) were used to summarize results of student performance and response to survey instrument. Overall score and subscale scores were converted to a percentage (0-100\%). Distribution of these variables were reviewed using QQ plots to determine if data are approximately normal. Differences in scores between pre-course change and post-course change were assessed using independent t-tests. Percent of students who failed the presentation was assessed using a Chi-Square test. Alpha for all statistical tests was set at 0.05. SAS 9.4 for Windows was used for all analyses. The study received Institutional Review Board approval (IRB\#4605).

\section{RESULTS}

The pre-course change group included 205 students ( $\mathrm{N}=106$ and 99 students in the class of 2016 and 2017, respectively) and the post-course change group included 165 students ( $\mathrm{N}=80$ and 85 students in the class of 2018 and 2019 , respectively). Overall presentation scores were available for all 370 students. There was no difference in the mean overall presentation grade pre- and post-course change, $85.5 \%$ versus $89.6 \%(\mathrm{p}=0.26)$. Subscores for specific sections of the rubric were not available for all students in the pre-course change group because evaluations from the distant campus were not available in the electronic database; subscores were available for $72(67.9 \%)$ and $70(70.7 \%)$ students in the classes of 2016 and 2017 respectively. However, subscores were available for 100\% of the post-course change group were available. Statistical differences in subscores were noted for the objectives, slides, and critical analysis, with the postcourse change group scoring lower on objectives and slides and higher on critical analysis. Table 1 includes a breakdown of the overall scores and subsection scores based on graduation year. No differences were noted in the percentage of students that scored $<70 \%$ and had to remediate the seminar presentation $(\mathrm{p}=0.6)$. In the pre-course change group, $7.5 \%$ and $5.9 \%$ had to remediate in the classes of 2016 and 2017, respectively, compared to $2.5 \%$ and $7.0 \%$ in the post-course change group for the classes of 2018 and 2019, respectively.

Student and faculty time commitment differed for the two time periods. For the weekly course design, students had significantly more in-class time with 38 hours of mandatory attendance (ie, 19 two-hour sessions) compared to 16 hours in the hybrid asynchronous and two-day conference format ( $\mathrm{p}=0.003$ ). Although the total number of full-time faculty involved in evaluating presentations was similar (20 in pre-course change vs. 18 in post-course change period), the total time commitment for in-class grading of presentations decreased significantly for the 10-minute presentation session with 72 hours in the pre-course change group and 36 hours in the post-course change group, $\mathrm{p}=0.001$. The total amount of in-class grading time faculty devoted to the 25 -minute presentation decreased from 101 to 83 hours, although this was not statistically significant.

A survey response was received from 34 (42.5\%) of the 2018 graduates. Figure 2 includes the student ratings of helpfulness of the asynchronous seminar preparation videos and corresponding quizzes. Overall, a majority of the students rated the preparation videos as helpful. Although a majority of students rated quizzes as "average helpfulness" for reinforcing information learned in the associated video, the students did not perceive them to be as helpful as the videos. When asked about overall satisfaction with the post- course change in the fall semester, the majority (94\%) were satisfied with 7 students (20.6\%) reporting being "extremely satisfied", 11 (32.4\%) being "above average satisfied", and 14 being "average satisfied". Responses were similar for the course in the spring semester with 10 students (29.4\%) being "extremely satisfied", 9 (26.5\%) being "above average satisfied", and $13(38.2 \%)$ being "average satisfied". When asked "would you have rather attended a weekly seminar course", a majority (79.4\%) of students answered "no" and would prefer to continue the two-day format.

Nine of the eleven (82\%) faculty who graded the spring presentations completed the faculty survey. Two faculty were not involved with grading in the previous course structure. Of those that were involved in the previous course structure, four faculty respondents $(57.1 \%)$ believed that the two-day course format had a lower workload and three respondents $(42.9 \%)$ believed that the workload was no different than previous years. No faculty respondents reported an increased workload from previous years. In regards to quality of presentations, responding faculty rated student presentations as being better $(14.3 \%)$ or similar $(85.7 \%)$ to previous years and no respondent considered presentations to 
be of poorer quality. When asked about preference of format for the seminar course, eight faculty respondents $(88.9 \%)$ selected the two-day format and one (11.1\%) selected a monthly format. Overall, satisfaction for the post-course change fall semester seminar course was rated as "extremely satisfied" by $22.2 \%$, "above average satisfied" by $44.4 \%$, or "average satisfied" by $11.1 \%$ of faculty respondents. Satisfaction for the spring semester was similar with $22.2 \%$ reporting "extremely satisfied" and $66.7 \%$ reporting "above average satisfied".

\section{DISCUSSION}

While US Doctor of Pharmacy programs vary in curricular design and semester length, a common traditional academic year format is two semesters that are 16 weeks each. ${ }^{14}$ Intensive courses that are accelerated in time can occur within a traditional four-year doctor of pharmacy program. While previous research about the use of intensive courses in traditional pharmacy programs are lacking, studies in health science programs with graduate students found no statistically significant differences on student performance or satisfaction. ${ }^{10}$ Our current study with pharmacy students in a professional program using a hybrid approach found similar results. The new intensive hybrid design did not affect the overall course performance (presentation grades); however, there were two statistical differences noted in the subscores for objectives and slides. The differences in scores for objectives and slides may have resulted from the pre-course change group having more hands-on time working with faculty on writing objectives and formatting slides. Of note, one additional difference was found with statistically higher critical analysis scores in the post-course changed group compared to the pre-course change group. This result may be due to curricular changes involving the P3 spring literature evaluation course in the previous year, and less likely due to the change in course delivery, as this skill is not directly taught in the seminar course. It is possible that adding an additional year of students to either group may have altered these results. Furthermore, it is important to consider that these differences may not be educationally significant as the mean subsection scores were similar in grade range. There were also no differences in the number of students that failed the presentation (ie, presentation score $<70 \%$ ) in the pre- and post-course change groups. Therefore, for the primary objective, the transition to an intensive hybrid design for a senior seminar course is feasible and the structure does not negatively impact students' overall performance. It is important to note that this is a core Doctor of Pharmacy course but it is primarily performance-based. A core course with more didactic instruction may not find similar results related to the transition or performance outcomes. However, this result may be appealing to programs that are hesitant to use an intensive design because of concerns about learning and performance outcomes.

For the second study objective, one reason to shift to an intensive course design is to achieve resource savings related to student and faculty time and this study demonstrated this outcome. The intensive hybrid design reduced faculty evaluation/grading time for the fall and spring sessions by almost 30\% compared to the traditional weekly class design. The faculty hours contributed for in-class grading of the 10-minute presentation had the most significant reduction, with a $50 \%$ decrease in hours. This result was due to the ability to run sessions in more rooms simultaneously with fewer breaks between presenters, leading to a more efficient use of time. For the 25 -minute presentation, there was only an $18 \%$ decrease in the faculty hours contributed to in-class grading of presentations; however, the course coordinators used more faculty to grade, but the grading was limited to either a morning or afternoon session based on availability. This allowed more faculty members to be involved because there was greater flexibility in scheduling. Student time away from APPE sites to attend in-classroom sessions was also reduced from 38 to 16 hours in the post-course change group. These hours did not include travel time from the APPE site to the college of pharmacy. However, the pre-course change group also likely missed more time away from the APPE site because they had to leave early to account for the drive-time to the college for 16 different class sessions. Less time away from the rotation site would likely be more appealing to APPE preceptors, since it would produce less disruptions to students' APPE schedule. Having students absent from the site for two full days during two specific months may be easier for preceptors to manage than students' weekly absences for two hours plus travel time each week for the semester.

Finally, for objective three, the intensive hybrid course design for the fall and spring was well-received by the majority of students and faculty. This result is important because it revealed that students and faculty perceived that an intensive hybrid course design maintained course outcomes, expectations, and performance. This result is limited by the low student survey response rate. This low response may be due to a lack of incentive to complete the survey since it was administered after the course was completed. Similarly, over $75 \%$ of faculty members who participated in both formats preferred the intensive hybrid course design over weekly meetings. Faculty perceived the workload to be similar or less than previous years and felt the quality of presentations remained the same.

There are two additional limitations of this study that should be noted. First, this study evaluated a single pharmacy program; student outcomes and acceptance by faculty and students may differ if this capstone course were conducted at another college of pharmacy. However, the data collection occurred over several years with many students and faculty, which should increase the generalizability to other programs. Second, a locally developed rubric was used to 
evaluate the presentations and has not been validated for use outside of our program. However, inter-rater reliability was established when this rubric was first utilized in the course. It is possible that different study results could be found if a different scoring rubric was used.

The intensive hybrid course design provided an ideal structure for virtual learning, which was made necessary during the COVID-19 pandemic. The only major change required was a transition from in-person to online video conferencing (i.e. Zoom) on the two meeting days. This allowed for quick changes based on frequently changing epidemiologic data and provides an additional group to compare and assess for future research.

\section{CONCLUSION}

Changing the format of a senior capstone seminar course from a weekly meeting to an intensive hybrid design led to a reduction in faculty workload and student time away from APPE rotations, while maintaining a similar level of quality presentations. Statistical difference in subscores for writing presentation objectives and slide development were noted for the post-course change group, so opportunities for hands-on practice of these skills may be needed. The majority of students and faculty were satisfied with the course design and preferred to continue the new format.

\section{REFERENCES}

1. Romanelli F. Seminar series course to teach essential knowledge and skills not covered in the traditional pharmacy curriculum. Am J Pharm Educ. 2008;72(4):84. Doi: 10.5688/aj720484.

2. Poirier TI. A seminar course on contemporary pharmacy issues. Am J Pharm Educ. 2008;72(2):30. Doi:10.5688/aj720230.

3. Ference JD, Medina MS. Modifying a traditional course for the PharmD curriculum. Am J Pharm Educ. 2008;72(5):122.

4. Saseen JJ, Linnebur SA, Borgelt LM, Trujillo J, Fish DN, Mueller S. A pharmacotherapy capstone course to target student learning and programmatic curricular assessment. Am J Pharm Edu. 2017;81(3):45. Doi: 10.5688/ajpe81345.

5. Medina MS, Schwier NC, Miller JL, Misty MM, Skrepnek GH. Career skills assessment in a doctor of pharmacy curriculum. Am J Pharm Educ. 2018;82(7):6300. Doi:10.5688/ajpe6300.

6. Beatty SJ, Kelley KA, Ha J, Matsunami M. Measuring preadvanced practice experience outcomes as part of a PharmD capstone experience. Am J Pharm Edu. 2014;78(8):152. Doi:10.5688/ajpe788152.

7. Vaidean GD, Vansal SS, Moore RJ, Feldman S. Student scientific inquiry in the core curriculum. Am J Pharm Edu. 2013;77(8):176. Doi: 10.5688/ajpe778176.

8. Slack MK, Martin J, Worede L, Islam S. A systematic review of extramural presentations and publications from pharamcy student research programs. Am J Pharm Edu. 2016;80(6):100. Doi:10.5688/ajpe806100.

9. Crawford SY. An innovative seminar course in business etiquette for pharmacy graduate students. Am J Pharm Educ. 2012;76(9):177. Doi: 10.5688/ajpe769177.

10. Harwood KJ, McDonald PL, Butler JT, Schlumpf KS. Comparing student outcomes in traditional vs. intensive, online graduate programs in health professional education. BMC Med Educ. 2018;18(1):240.

11. Coons JC, Benedict N, Seybert A, Iasella CJ, Skledar SJ, Smith RM, Saul M, Ensor CR. A pharmacotherapy scholars program to provide intensive training to enhance pharmacy students' postgraduate readiness. Am J Pharm Educ. 2019;83(9):7327.

12. Davies WM. Intensive teaching formats: A review. Issues in Educ Res. 2006;16(1):1-21.

13. Van Scyoc LJ, Gleason J. Traditional or intensive course lengths? A comparison of outcomes in economics learning. J Econ Educ. 1993;24(1):15-22.

14. Howard University College of Pharmacy. Types of Pharm D programs. Accessed September 9, 2021. https://www.pharmdprograms.org/types-of-pharmd-programs/. 
Table 1. Overall grade and subsection grades for 25 -minute presentation

\begin{tabular}{|c|c|c|c|c|c|c|c|c|}
\hline & $\begin{array}{c}\text { Pre-Course } \\
\text { Change } \\
{[2016-2017]} \\
(n=205)\end{array}$ & $\begin{array}{c}2016 \\
(n=106)\end{array}$ & $\begin{array}{c}2017 \\
(n=99)\end{array}$ & $\begin{array}{c}\text { Post-Course } \\
\text { Change } \\
\text { [2018-2019] } \\
(n=165)\end{array}$ & $\begin{array}{c}2018 \\
(n=80)\end{array}$ & $\begin{array}{c}2019 \\
(n=85)\end{array}$ & $\begin{array}{c}\text { Difference in } \\
\text { Pre vs. Post- } \\
\text { Course } \\
\text { Change }\end{array}$ & p-value \\
\hline \multicolumn{9}{|c|}{ Mean + Standard Deviation } \\
\hline $\begin{array}{l}\text { Overall } \\
\text { grade }(\%)\end{array}$ & $\begin{array}{c}85.5 \pm 8.7 \\
\text { (Range, 59.5- } \\
100.0)\end{array}$ & $\begin{array}{c}85.0 \pm 8.6 \\
\text { (Range, 60.0- } \\
100.0)\end{array}$ & $\begin{array}{c}86.1 \pm 8.8 \\
\text { (Range, 59.5- } \\
98.5)\end{array}$ & $\begin{array}{c}86.6 \pm 9.8 \\
\text { (Range, } 41.5- \\
100.0)\end{array}$ & $\begin{array}{c}89.0 \pm 8.7 \\
(\text { Range, } 54.0- \\
100.0)\end{array}$ & $\begin{array}{c}84.4 \pm 10.4 \\
\text { (Range, } 41.5- \\
100.0)\end{array}$ & $\begin{array}{c}1.1(-0.83 \text { to } \\
3.02)\end{array}$ & 0.26 \\
\hline $\begin{array}{l}\text { Objectives } \\
\text { Subscore } \\
\text { (\% of max } \\
\text { points) }\end{array}$ & $97.1 \pm 10.2$ & $97.5 \pm 6.0^{+}$ & $96.7 \pm 13.2 *$ & $93.9 \pm 15.8$ & $93.2 \pm 20.5$ & $94.5 \pm 9.8$ & $\begin{array}{c}-3.18(-6.13 \text { to }- \\
0.22)\end{array}$ & 0.035 \\
\hline $\begin{array}{l}\text { Handout } \\
\text { Subscore } \\
\text { (\% of max } \\
\text { points) }\end{array}$ & $86.9 \pm 12.0$ & $86.2 \pm 11.2^{+}$ & $87.6 \pm 12.8^{*}$ & $88.0 \pm 11.8$ & $89.6 \pm 10.7$ & $86.6 \pm 12.6$ & $\begin{array}{c}1.16(-1.52 \text { to } \\
3.84)\end{array}$ & 0.39 \\
\hline $\begin{array}{l}\text { Slides } \\
\text { Subscore } \\
\text { (\% of max } \\
\text { points) }\end{array}$ & $92.6 \pm 10.7$ & $91.3 \pm 11.5^{+}$ & $94.0 \pm 9.7 *$ & $88.8 \pm$ & $91.6 \pm 11.8$ & $86.2 \pm 16.7$ & $\begin{array}{c}-3.79(-6.66 \text { to }- \\
0.92)\end{array}$ & 0.012 \\
\hline $\begin{array}{l}\text { Assessment } \\
\text { Questions } \\
\text { Subscore } \\
\text { (\% of max } \\
\text { points) }\end{array}$ & $86.7 \pm 20.2$ & $91.5 \pm 17.3^{+}$ & $81.8 \pm 21.8 *$ & $81.9 \pm 27.2$ & $87.8 \pm 22.2$ & $76.3 \pm 30.2$ & $\begin{array}{c}-4.81(-10.14 \text { to } \\
0.52)\end{array}$ & 0.083 \\
\hline $\begin{array}{l}\text { Critical } \\
\text { Analysis } \\
\text { Subscore } \\
\text { (\% of max } \\
\text { points) }\end{array}$ & $79.4 \pm 14.2$ & $78.9 \pm 14.1^{+}$ & $79.9 \pm 14.4^{*}$ & $83.4 \pm 16.4$ & $86.6 \pm 14.9$ & $80.4 \pm 17.3$ & $\begin{array}{c}3.99(0.55 \text { to } \\
7.43)\end{array}$ & 0.025 \\
\hline
\end{tabular}

${ }^{+} \mathrm{n}=72 *{ }^{n}=70$ 
Figure 1. Spring 25-minute presentation rubric

\begin{tabular}{|c|c|c|c|}
\hline TALK INTRODUCTION & \multirow{2}{*}{$\begin{array}{c}\begin{array}{c}\text { Points } \\
\text { Possible }\end{array} \\
1\end{array}$} & $\begin{array}{l}\text { Points } \\
\text { Earned }\end{array}$ & Comments \\
\hline $\begin{array}{l}\text { 1. Complete title slide included in presentation (name, affiliation, } \\
\text { date, and title of talk) }\end{array}$ & & & \\
\hline $\begin{array}{l}\text { Incomplete title slide (missing elements: name, affiliation, date, or } \\
\text { talk title) }\end{array}$ & 0.5 & & \\
\hline No title slide offered & 0 & & \\
\hline \multirow{2}{*}{$\begin{array}{l}\text { 2. Offered a clear and engaging introduction of talk (ie, "Hook") } \\
\text { Introduction was vague, unengaging/less compelling }\end{array}$} & 2 & & \\
\hline & 1 & & \\
\hline No introduction provided & 0 & & \\
\hline $\begin{array}{l}\text { 3. Offered a specific verbal overview of talk (reviewed goals \& } \\
\text { objectives or a specific outline/agenda) }\end{array}$ & 1 & & \\
\hline Offered a vague verbal overview of talk & 0.5 & & \\
\hline No overview provided & 0 & & \\
\hline 4. $\quad$ Appropriate number of objectives for presentation length ( 3 or 4$)$ & 2 & & \\
\hline \multirow{2}{*}{$\begin{array}{l}\text { Acceptable number of objectives for presentation length }(2 \text { or } 5) \\
\text { Inappropriate number of objectives for presentation length }(1 \text { or } 6)\end{array}$} & 1.5 & & \\
\hline & 1 & & \\
\hline No objectives created for talk & 0 & & \\
\hline $\begin{array}{l}\text { 5. All verbs used in each objective are measurable and a different } \\
\text { verb is used for each objective }\end{array}$ & 1 & & \\
\hline $\begin{array}{l}\text { Some of the objectives use verbs that are NOT measurable (eg, } \\
\text { some - know/understand) and/or some of the objective verbs are } \\
\text { used more than once }\end{array}$ & 0.5 & & \\
\hline $\begin{array}{l}\text { No measurable objectives (used "know", "understand") OR same } \\
\text { verb used for all objectives }\end{array}$ & 0 & & \\
\hline HANDOUT - AMOUNT OF MEANINGFUL INFORMATION & $\begin{array}{c}\text { Points } \\
\text { Possible }\end{array}$ & $\begin{array}{l}\text { Points } \\
\text { Earned }\end{array}$ & Comments \\
\hline $\begin{array}{l}\text { 1. Handout was not written in full sentences (used summarized } \\
\text { sentences/paraphrased). Maximum of } 4 \text { pages ( } 2 \text { pages } \\
\text { front/back). }\end{array}$ & 1 & & \\
\hline Handout written use full sentences & 0 & & \\
\hline $\begin{array}{l}\text { 2. The handout outline provided information that could serve as a } \\
\text { reference in the future }\end{array}$ & 1 & & \\
\hline $\begin{array}{l}\text { The handout outline was missing information that limited its use as } \\
\text { a reference in the future }\end{array}$ & 0.5 & & \\
\hline $\begin{array}{l}\text { The handout outline provided little to no information that could } \\
\text { serve as a reference in the future (eg, was skeletal in nature or 1-2 } \\
\text { words per line) }\end{array}$ & 0 & & \\
\hline HANDOUT FORMAT & $\begin{array}{l}\text { Points } \\
\text { Possible }\end{array}$ & $\begin{array}{l}\text { Points } \\
\text { Earned }\end{array}$ & Comments \\
\hline $\begin{array}{l}\text { 1. Handout has a heading/title including } 4 \text { elements: name, date, } \\
\text { course, title of talk }\end{array}$ & 1 & & \\
\hline Handout heading missing 1 or more of the 4 elements & 0.5 & & \\
\hline Handout has no heading/title and none of the 4 elements & 0 & & \\
\hline $\begin{array}{l}\text { 2. Handout includes page numbers and used formal font (eg, Arial, } \\
\text { Times New Roman) }\end{array}$ & 1 & & \\
\hline $\begin{array}{l}\text { Handout pages not numbered or used informal font (eg, Comic } \\
\text { sans, Curlz) }\end{array}$ & 0 & & \\
\hline \multirow{2}{*}{$\begin{array}{l}\text { 3. Entire handout used formal roman numeral format (overall) } \\
\text { Inconsistent use of roman numeral format in handout (used some } \\
\text { bullets instead) }\end{array}$} & 1 & & \\
\hline & 0.5 & & \\
\hline Entire handout formatted using bullets or paragraphs & 0 & & \\
\hline $\begin{array}{l}\text { 4. Handout included a complete and properly formatted reference } \\
\text { section }\end{array}$ & 1 & & \\
\hline
\end{tabular}




\begin{tabular}{|c|c|c|c|}
\hline $\begin{array}{l}\text { The reference section was improperly formatted, missing or } \\
\text { incomplete }\end{array}$ & 0 & & \\
\hline The entire handout was free from spelling or grammar mistakes & 1 & & \\
\hline The handout contained 1-2 spelling or grammar mistakes & 0.5 & & \\
\hline The handout contained $\geq 3$ spelling or grammar mistakes & 0 & & \\
\hline VISUAL/LEARNING AIDS - SLIDES & $\begin{array}{l}\text { Points } \\
\text { Possible }\end{array}$ & $\begin{array}{l}\text { Points } \\
\text { Earned }\end{array}$ & Comments \\
\hline $\begin{array}{l}\text { 1. Appropriate blue-colored slide \& plain background \& light } \\
\text { colored text (yellow title, white content) }\end{array}$ & 1 & & \\
\hline $\begin{array}{l}\text { Acceptable dark colored slide, plain background with light colored } \\
\text { text (readable), not distracting }\end{array}$ & 0.5 & & \\
\hline $\begin{array}{l}\text { Unacceptable slide, background, text (poor color choices, } \\
\text { distracting, unreadable, poor background) }\end{array}$ & 0 & & \\
\hline $\begin{array}{l}\text { 2. Appropriate font (Arial -san serif), text size, and amount of text on } \\
\text { majority of slides }\end{array}$ & 1 & & \\
\hline $\begin{array}{l}\text { Unacceptable font (Times New Roman -serif), OR text size } \\
\text { (unreadable point size), OR amount of text on majority of slides } \\
\text { (too much/too little - exact talk wording) }\end{array}$ & 0 & & \\
\hline $\begin{array}{l}\text { 3. The majority pictures, tables or graphs were of quality and/or } \\
\text { were meaningful/relevant }\end{array}$ & 1 & & \\
\hline $\begin{array}{l}\text { The majority pictures, tables or graphs were relevant but of poor } \\
\text { quality }\end{array}$ & 0.5 & & \\
\hline $\begin{array}{l}\text { The pictures/tables/graphs were trivial/not relevant or no } \\
\text { pictures/tables/graphs were used on slides }\end{array}$ & 0 & & \\
\hline VISUAL/LEARNING AIDS - SLIDES (CONT) & $\begin{array}{c}\text { Points } \\
\text { Possible } \\
\end{array}$ & $\begin{array}{l}\text { Points } \\
\text { Earned }\end{array}$ & Comments \\
\hline $\begin{array}{l}\text { 4. Highlighted information on pictures, tables, graphs or text using } \\
\text { arrows, boxes, circles, etc }\end{array}$ & 1 & & \\
\hline $\begin{array}{l}\text { No highlighting tools used on pictures, tables, graphs or on text } \\
\text { (did not use bold, color, underline) }\end{array}$ & 0 & & \\
\hline $\begin{array}{ll}5 . & \text { Professional slides - simple (circle/square) bullets used on all text } \\
\text { slides, organized content layout, no typos, acceptable grammar }\end{array}$ & 1 & & \\
\hline $\begin{array}{l}\text { Unprofessional slides -distracting/elaborate style bullets (or no } \\
\text { bullets used or bullets inconsistently used), unorganized content } \\
\text { layout, typos, unacceptable grammar }\end{array}$ & 0 & & \\
\hline REVIEW OF/ELABORATION OF TOPIC CONTENT & $\begin{array}{c}\text { Points } \\
\text { Possible }\end{array}$ & $\begin{array}{l}\text { Points } \\
\text { Earned }\end{array}$ & Comments \\
\hline $\begin{array}{l}\text { 1. Well balanced (higher and lower level information) topic } \\
\text { presented with relevant information presented. All } \\
\text { aspects/options of topic reviewed. }\end{array}$ & 10 & & \\
\hline $\begin{array}{l}\text { Adequately balanced (higher \&lower level)-mostly relevant } \\
\text { information presented. Many options discussed. }\end{array}$ & 8 & & \\
\hline $\begin{array}{l}\text { Topic presented too narrowly or broadly (too lower level), few or } \\
\text { irrelevant options discussed. }\end{array}$ & 6 & & \\
\hline $\begin{array}{l}\text { Not enough or completely irrelevant information presented, no } \\
\text { options discussed }\end{array}$ & 3 & & \\
\hline $\begin{array}{ll}\text { 2. Incorporated relevant literature from reputable journals in talk. } \\
\text { Insightful analysis of literature. }\end{array}$ & 10 & & \\
\hline $\begin{array}{l}\text { Incorporated mostly relevant literature in talk (in mostly reputable } \\
\text { journals). Literature analysis limited to author's conclusions, some } \\
\text { interpretation of data. }\end{array}$ & 8 & & \\
\hline $\begin{array}{l}\text { Little primary literature used, few reputable journals used, little } \\
\text { analysis of literature, recited data }\end{array}$ & 6 & & \\
\hline $\begin{array}{l}\text { Relied on secondary or tertiary articles (relevant articles missed), } \\
\text { almost no reputable journals cited, current literature not cited, no } \\
\text { analysis of literature, no interpretation of data. }\end{array}$ & 3 & & \\
\hline $\begin{array}{l}\text { 3. Thorough critique of topic; position well justified using literature } \\
\text { ( } \geq \mathbf{2} \text { studies) as evidence, not journal club style }\end{array}$ & 10 & & \\
\hline
\end{tabular}




\begin{tabular}{|c|c|c|c|}
\hline $\begin{array}{l}\text { Adequate critique of topic, some positions adequately justified } \\
\text { using literature ( } \geq 2 \text { studies), or some evidence presented journal } \\
\text { club style }\end{array}$ & 8 & & \\
\hline $\begin{array}{l}\text { Little critique of topic with positions not well justified using } \\
\text { literature ( } \leq 2 \text { studies), most evidence journal club style }\end{array}$ & 6 & & \\
\hline $\begin{array}{l}\text { No critique and no justification of position, } \leq 2 \text { articles/evidence } \\
\text { used, all evidence journal club style }\end{array}$ & 3 & & \\
\hline $\begin{array}{l}\text { 4. Organization of content - Presentation flowed logically and was } \\
\text { clear. Used deliberate transitions. }\end{array}$ & 6 & & \\
\hline $\begin{array}{l}\text { Generally well organized; occasionally skipped around. } \\
\text { Acceptable verbal transitions }\end{array}$ & 4 & & \\
\hline Difficult to follow, more logical flow needed. No transitions used. & 2 & & \\
\hline 5. $\begin{array}{l}\text { Amount of content and amount of time spent on the major } \\
\text { sections of the presentation were appropriate }\end{array}$ & 6 & & \\
\hline $\begin{array}{l}\text { Adequate amount of content and time on most of the major } \\
\text { sections of the presentation }\end{array}$ & 4 & & \\
\hline $\begin{array}{l}\text { Inadequate amount of content and time on most of the major } \\
\text { sections of the presentation (eg, majority of time spent on } \\
\text { background material) }\end{array}$ & 2 & & \\
\hline REVIEW OF/ELABORATION OF TOPIC CONTENT (CONT) & $\begin{array}{c}\text { Points } \\
\text { Possible }\end{array}$ & $\begin{array}{l}\text { Points } \\
\text { Earned }\end{array}$ & Comments \\
\hline $\begin{array}{l}\text { 6. Student was knowledgeable about subject matter. Able to clearly } \\
\text { explain all concepts. }\end{array}$ & 4 & & \\
\hline $\begin{array}{l}\text { Student somewhat knowledgeable about subject matter. Able to } \\
\text { clearly explain some concepts }\end{array}$ & 3 & & \\
\hline $\begin{array}{l}\text { Student was not knowledgeable about subject matter. Unable to } \\
\text { clearly explain most concepts }\end{array}$ & 1 & & \\
\hline Provided a thorough and complete summary/review & 2 & & \\
\hline Provided a vague or incomplete summary/review & 1 & & \\
\hline No summary/review provided & 0 & & \\
\hline $\begin{array}{l}\text { 8. Provided insightful conclusions with recommendations, future } \\
\text { directions, what's next/useful }\end{array}$ & 4 & & \\
\hline $\begin{array}{l}\text { Provided a vague or incomplete conclusion with few } \\
\text { recommendations, future directions, what to do }\end{array}$ & 2 & & \\
\hline $\begin{array}{l}\text { No conclusions or useful recommendations, future directions, } \\
\text { what's next/useful to do provided }\end{array}$ & 0 & & \\
\hline CRITICAL ANALYSIS & $\begin{array}{c}\text { Points } \\
\text { Possible }\end{array}$ & $\begin{array}{l}\text { Points } \\
\text { Earned }\end{array}$ & Comments \\
\hline $\begin{array}{l}\text { 1. Discussion of study design AND clinical/statistical significance } \\
\text { provided, interpretation accurate/appropriate }\end{array}$ & 6 & & \\
\hline $\begin{array}{l}\text { Discussion of study design AND clinical/statistical significance } \\
\text { provided, but interpretation not completely accurate }\end{array}$ & 4 & & \\
\hline $\begin{array}{l}\text { Partially presented study design and/or clinical/statistical } \\
\text { significance OR incorrect interpretation of data }\end{array}$ & 2 & & \\
\hline No discussion of study design OR clinical/statistical significance & 0 & & \\
\hline ACTIVE LEARNING REQUIREMENT & $\begin{array}{c}\text { Points } \\
\text { Possible }\end{array}$ & $\begin{array}{l}\text { Points } \\
\text { Earned }\end{array}$ & Comments \\
\hline 1. Included at least one higher level active learning strategy & 1 & & \\
\hline No active learning strategy used & 0 & & \\
\hline $\begin{array}{l}\text { 2. Controlled active learning - gave clear and specific instructions } \\
\text { for activity }\end{array}$ & 1 & & \\
\hline No instructions offered for activity or instructions were not clear & 0 & & \\
\hline COMMUNICATION SKILLS - PRESENTATION STYLE & $\begin{array}{c}\text { Points } \\
\text { Possible } \\
\end{array}$ & $\begin{array}{l}\text { Points } \\
\text { Earned }\end{array}$ & Comments \\
\hline $\begin{array}{l}\text { Voice - Consistent and appropriate volume, rate, enunciation, tone, } \\
\text { and vocal variety }\end{array}$ & 1 & & \\
\hline Inconsistent volume, rate, enunciation, tone, and vocal variety & 0.5 & & \\
\hline Inaudible, incomprehensible, monotone, poor rate and tone & 0 & & \\
\hline
\end{tabular}




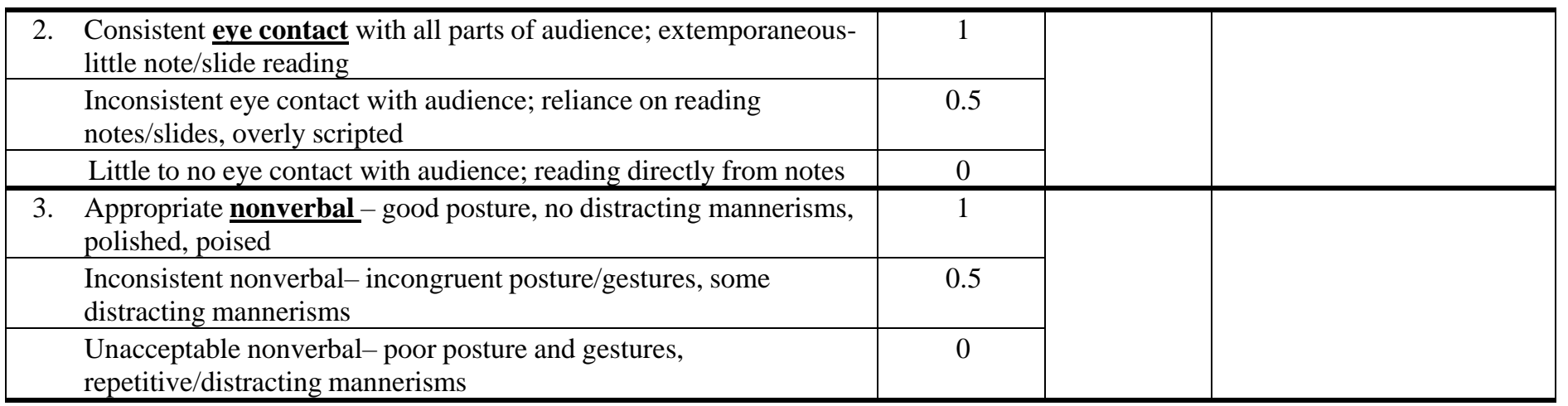


Unacceptable pace (too fast or too slow)

\begin{tabular}{|c|c|c|c|}
\hline Unacceptable pace (too fast or too slow) & 0 & & \\
\hline 2. 25 minutes $($ range $=20-30 \mathrm{~min})($ time for questions not counted $)$ & 4 & & \\
\hline 18-19 minutes OR 31-32 minutes & 2 & & \\
\hline 16-17 minutes OR 33-34 minutes & 1 & & \\
\hline $\begin{array}{l}15 \mathrm{~min} \text { and under OR } 35 \mathrm{~min} \text { and over (This timeframe may result } \\
\text { in seminar failure and require seminar repeat) }\end{array}$ & 0 & & \\
\hline OVERALL PROFESSIONALISM & $\begin{array}{c}\text { Points } \\
\text { Possible }\end{array}$ & $\begin{array}{l}\text { Points } \\
\text { Earned }\end{array}$ & Comments \\
\hline $\begin{array}{l}\text { 1. Appropriate dress, tone, and attitude; positive role model for future } \\
\text { presenters }\end{array}$ & 1 & & \\
\hline $\begin{array}{l}\text { Informal dress, tone, and attitude; questionable role model for } \\
\text { future presenters }\end{array}$ & 0.5 & & \\
\hline $\begin{array}{l}\text { Inappropriate dress, tone, and attitude; negative role model for } \\
\text { future presenters }\end{array}$ & 0 & & \\
\hline OVERALL IMPRESSION & $\begin{array}{c}\text { Points } \\
\text { Possible }\end{array}$ & $\begin{array}{c}\text { Points } \\
\text { Earned }\end{array}$ & Comments \\
\hline 1. Outstanding & 4 & & \\
\hline Meets expectations & 3 & & \\
\hline Needs significant improvements & 1 & & \\
\hline Unsatisfactory & 0 & & \\
\hline
\end{tabular}


Figure 2. Student rating of helpfulness of preparation videos, quizzes, and grading rubric $(\mathrm{n}=34)$

Section Statement ltem

Seminar Rate how helpfut 1. writing objectives Preparation the seminar

Videos preparation

videos were for: 2 , writing assessment questions

3. preparing slides

4. presentation skils

4. presentation skills

5. referencing the literature

6. slide animation

7. a biostatistics refresher

Total

Preparation Rate how helpful 8. CV/resume

Preparation Rate how helpful development video for reinforcing

for reinforcing

information you 9 . thank you note learned from the: writing video

10. presentation skills video

11. creating slides video

12. preparing handout video

13. referencing video

14. writing objectives video

15. writing assessment questions video

6. biostatistics review

16. biostatistics revie video

17. example presentation video

Total

$\begin{array}{ll}\text { Rate how helpful 18. presentation } & \end{array}$ the seminar
rubric was for: preparation

Grading

Rubric

Total

Grand Total

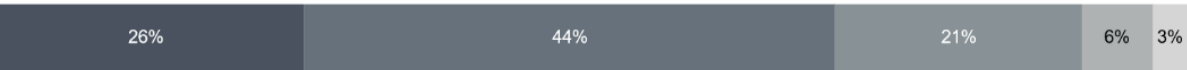

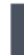

2

$24 \% \quad 35 \%$

$50 \%$

$32 \%$

$32 \%$

$6 \% \quad 3 \%$

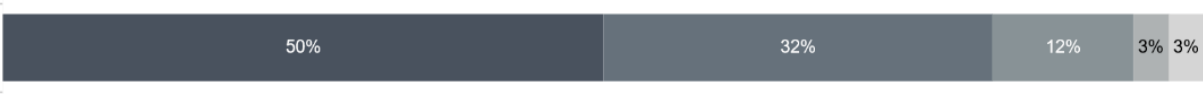

\begin{tabular}{|l|l|l|l}
\hline $32 \%$ & $32 \%$ & $26 \%$ & $6 \%$
\end{tabular}

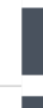

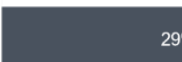

$29 \%$

$38 \%$

$21 \%$

$9 \% \quad 3 \%$

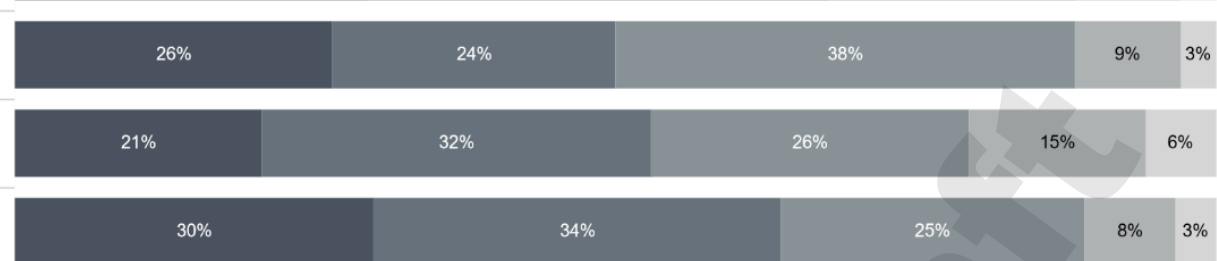

$12 \%$

$21 \%$

$53 \%$

$9 \%$

$6 \%$

$15 \%$

$24 \%$

$41 \%$

$12 \%$

$9 \%$

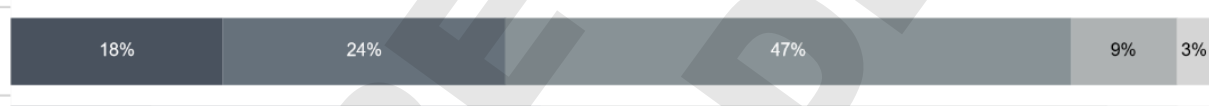

\begin{tabular}{ll|l|l}
$12 \%$ & $32 \%$ & $47 \%$ & $6 \%$
\end{tabular}

\begin{tabular}{lllll}
\hline $18 \%$ & $29 \%$ & $44 \%$ & $6 \%$ & $3 \%$
\end{tabular}

\begin{tabular}{|l|l|ll}
\hline $18 \%$ & $32 \%$ & $41 \%$ & $6 \%$
\end{tabular}

\begin{tabular}{l|l|l|l}
\hline $15 \%$ & $24 \%$ & $50 \%$ & $9 \%$ \\
\hline
\end{tabular}

$15 \%$

$26 \%$

$47 \%$

$9 \% \quad 3 \%$

\begin{tabular}{|c|c|c|c|c|}
\hline $9 \%$ & $24 \%$ & $38 \%$ & $21 \%$ & $9 \%$ \\
\hline
\end{tabular}

\begin{tabular}{|c|c|c|c|c|c|}
\hline $26 \%$ & $21 \%$ & $38 \%$ & & $6 \%$ & $9 \%$ \\
\hline $16 \%$ & $26 \%$ & $45 \%$ & & $9 \%$ & $5 \%$ \\
\hline & $71 \%$ & & $21 \%$ & & $9 \%$ \\
\hline & $71 \%$ & & $21 \%$ & & $9 \%$ \\
\hline
\end{tabular}

Legend: Item Response

Not at All Helpful

Less Than Average Helpfulness

Average Helpfulness

Above Average Helpfulness

Extremely Helpful 